\title{
Serological survey of the novel influenza A H1N1 in inner city Winnipeg, Manitoba, 2009
}

\author{
Laura H Thompson MSc ${ }^{1}$, Salaheddin M Mahmud MD PhD ${ }^{1}$, Yoav Keynan MD ${ }^{2,3}$, James F Blanchard MD PhD ${ }^{1}$, \\ Joyce Slater $\mathrm{PhD}^{4}$, Magdy Dawood $\mathrm{PhD}^{2,5}$, Keith Fowke $\mathrm{PhD}^{1,2}$, Paul Van Caeseele $\mathrm{MD}^{2,5}$, Marissa Becker MD $\mathrm{D}^{1,2,3}$
}

LH Thompson, SM Mahmud, Y Keynan, et al. Serological survey of the novel influenza A H1N1 in inner city Winnipeg, Manitoba, 2009. Can J Infect Dis Med Microbiol 2012;23(2):6570.

INTRODUCTION: Little is known about the determinants of pandemic H1N1 (pH1N1) infection in Canada among low-income, inner city populations. To inform future influenza planning, the seroprevalence of pH1N1 antibodies among inner city clinic attendees in Winnipeg (Manitoba) according to sociodemographic and risk factor characteristics were estimated and vaccination rates were explored.

METHODS: Adults presenting to three inner city community clinics in Winnipeg from October 2009 to December 2009 were recruited as study participants $(n=458)$. A questionnaire was administered to collect demographic, risk factor and symptom information, and a venous blood sample was collected for hemagglutination inhibition assay testing to detect the presence of antibodies against pH1N1.

RESULTS: Approximately one-half (53\%) of the study participants reported an annual household income of $<\$ 10,000 /$ year, and $65 \%$ identified as Aboriginal. pH1N1 positivity was $5.7 \%$ among those enrolled early in the study and $15.5 \%$ among those enrolled later in the study. Positivity was higher among participants who were female, Aboriginal and in contact with children $\leq 5$ years of age. The overall pH1N1 vaccination rate was $28 \%$.

DISCUSSION: pH1N1 positivity was high among low-income adults accessing clinics in Winnipeg's inner city compared with the general population. Of further concern were the low rates of uptake of both seasonal and $\mathrm{pH} 1 \mathrm{~N} 1$ influenza vaccinations. When planning for future influenza outbreaks, it is important to incorporate strategies for the prevention, control, and care of influenza among low-income and inner city adults.

Key Words: Epidemiology; Hemagglutination inhibition assay; Inner city; Pandemic Influenza A H1N1; pH1N1; Serological survey

\section{Une enquête sérologique sur le nouveau virus de la grippe $\mathrm{A} \mathrm{H} 1 \mathrm{~N} 1$ dans les quartiers centraux de Winnipeg, au Manitoba, en 2009}

INTRODUCTION : On ne sait pas grand-chose des déterminants de l'infection par la grippe pandémique H1N1 (pH1N1) dans les quartiers centraux du Canada. Pour étayer la future planification de la grippe, les chercheurs ont estimé la séroprévalence des anticorps du virus pH1N1 chez les personnes qui fréquentent une clinique des quartiers centraux de Winnipeg, au Manitoba, d'après les caractéristiques sociodémographiques et sur le plan des facteurs de risque, et ils ont examiné les taux de vaccination.

MÉTHODOLOGIE : Les chercheurs ont recruté les adultes qui se sont présentés à trois cliniques communautaires des quartiers centraux de Winnipeg entre octobre et décembre 2009 à titre de participants à l'étude $(\mathrm{n}=458)$. Ils ont utilisé un questionnaire pour colliger de l'information sur la démographie, les facteurs de risque et les symptômes et prélevé un échantillon de sang veineux pour procéder à un test d'inhibition de l'hémagglutination afin de déceler la présence d'anticorps contre le virus pH1N1.

RÉSULTATS : Environ la moitié (53\%) des participants à l'étude, dont $65 \%$ étaient Autochtones, ont déclaré avoir un revenu familial annuel inférieur à 10000 \$. La positivité au virus pH1N1 était de 5,7\% chez les participants en début d'étude et de $15,5 \%$ chez les personnes qui y ont participé plus tard. La positivité était plus élevée chez les participants de sexe féminin, autochtones ou en contact avec des enfants de cinq ans et moins. Le taux de vaccination global contre le virus pH1N1 s'élevait à $28 \%$.

EXPOSÉ : La positivité au virus pH1N1 était élevée chez les adultes à faible revenu qui fréquentaient des cliniques des quartiers centraux de Winnipeg par rapport à la population générale. Par ailleurs, le faible taux de vaccination contre l'influenza saisonnière et contre la grippe $\mathrm{pH} 1 \mathrm{~N} 1$ était inquiétant. Dans le cadre de la planification de futures éclosions d'influenza, il sera important d'intégrer des stratégies de prévention, de contrôle et de soins de l'influenza chez les adultes à faible revenu des quartiers centraux.

\begin{abstract}
A novel H1N1 influenza A virus began causing severe cases of respiratory illness in March 2009 in Mexico. On April 23, 2009, the first Canadian cases were detected among a group of children from Nova Scotia who had just returned from a school trip to Mexico (1). Subsequently, pandemic H1N1 (pH1N1) spread to the rest of Canada. Since the first confirmed case of pH1N1 in Manitoba on May 3, 2009, there have been two pH1N1 epidemic waves: one between mid-May 2009 and the end of June 2009, and the other during the 2009/2010 influenza season, which occurred predominantly between October 2009 and December 2009. A total of 803 laboratory-confirmed cases of pH1N1 (2) were reported during the first wave, and an additional 1866 laboratory-confirmed cases were reported during the second wave (3). This likely under-represents the true incidence of $\mathrm{pH} 1 \mathrm{~N} 1$ because many infected individuals would not have sought medical attention regardless of whether they had symptoms. In addition, not

all infected individuals who did seek medical care would have been tested, further narrowing the number of infected individuals who were identified as cases. Testing was restricted to individuals for whom antiviral treatment would be indicated and those admitted to hospital with severe respiratory illness or influenza-like illness (ILI) (4), and involved nucleic acid amplification testing of nasopharyngeal sputum specimens. During the first wave of the Canadian pandemic, hospitalization and severe outcomes seemed to be most common among children $<2$ years of age, pregnant women, persons $<65$ years of age with underlying medical conditions and Aboriginal persons (5). Previous studies have indicated that hard-to-reach groups and marginalized populations are at greater risk of severe disease and these same groups also tend to have lower rates of immunizations $(6,7)$. Little is known about the prevalence and determinants of pH1N1 infection among low-income, inner city populations in Canada.
\end{abstract}

${ }^{1}$ Community Health Sciences; ${ }^{2}$ Medical Microbiology; ${ }^{3}$ Internal Medicine; ${ }^{4}$ Human Nutritional Sciences, University of Manitoba; ${ }^{5}$ adham

Provincial Laboratory, Winnipeg, Manitoba

Correspondence: Ms Laura H Thompson, Centre for Global Public Health, University of Manitoba, R070 - 771 McDermot Avenue, Winnipeg,

Manitoba R3E 0T6. Telephone 204-789-3245, fax 204-789-3718, e-mail thompsol@cc.umanitoba.ca 
TABLE 1

Distribution of sociodemographic and risk factor characteristics according to eligibility criterion change

\begin{tabular}{|c|c|c|c|c|}
\hline & $\mathbf{n}$ & $\begin{array}{c}\text { Group A*, } \\
\text { n (\%) }\end{array}$ & $\begin{array}{c}\text { Group } \mathbf{B}^{\dagger}, \\
\text { n (\%) }\end{array}$ & $\begin{array}{c}\text { Group } \mathbf{C}^{\ddagger} \\
\text { n (\%) }\end{array}$ \\
\hline Total & 458 & $174(38.0)$ & $206(45.0)$ & $78(17.0)$ \\
\hline Female & 211 & $88(50.6)$ & $87(42.2)$ & $36(46.2)$ \\
\hline \multicolumn{5}{|l|}{ Ethnicity } \\
\hline Aboriginal & 296 & $99(56.9)$ & $142(68.9)$ & 55 (70.5) \\
\hline Caucasian & 127 & $58(33.3)$ & $50(24.3)$ & $19(24.4)$ \\
\hline Other & 35 & $17(9.8)$ & $14(6.8)$ & $4(5.1)$ \\
\hline \multicolumn{5}{|l|}{ Age, years } \\
\hline $18-29$ & 120 & $41(23.6)$ & $66(32.0)$ & $13(16.7)$ \\
\hline 30-39 & 97 & $52(29.9)$ & $30(14.6)$ & $15(19.2)$ \\
\hline $40-49$ & 147 & $56(32.2)$ & $60(29.1)$ & $31(39.7)$ \\
\hline $50+$ & 94 & $25(14.4)$ & $50(24.3)$ & $19(24.4)$ \\
\hline \multicolumn{5}{|l|}{ High school graduate } \\
\hline Yes & 191 & $81(46.6)$ & $81(39.3)$ & $29(37.2)$ \\
\hline No & 236 & $84(48.3)$ & $113(54.9)$ & $39(50.0)$ \\
\hline Unknown & 31 & $9(5.2)$ & $12(5.8)$ & $10(12.8)$ \\
\hline \multicolumn{5}{|l|}{ Employed } \\
\hline No & 342 & $122(70.1)$ & $155(75.2)$ & 65 (83.3) \\
\hline Yes & 111 & $50(28.7)$ & $48(23.3)$ & $13(16.7)$ \\
\hline Unknown & 5 & $2(1.1)$ & $3(1.5)$ & $0(0.0)$ \\
\hline \multicolumn{5}{|c|}{ Annual household income } \\
\hline$<\$ 10,000$ & 126 & $44(25.3)$ & $62(30.1)$ & $20(25.6)$ \\
\hline$\$ 10,000-29,999$ & 51 & $32(18.4)$ & $15(7.3)$ & $4(5.1)$ \\
\hline$\geq \$ 30,000$ & 242 & $81(46.6)$ & $113(54.9)$ & $48(61.5)$ \\
\hline Unknown & 39 & $17(9.8)$ & $16(7.8)$ & $6(7.7)$ \\
\hline \multicolumn{5}{|l|}{ Location of residence } \\
\hline Inner city & 290 & $106(60.9)$ & $133(64.6)$ & $51(65.4)$ \\
\hline Suburb/rural & 91 & $40(23.0)$ & $42(20.4)$ & $9(11.5)$ \\
\hline Unknown & 77 & $28(16.1)$ & $31(15.0)$ & $18(23.1)$ \\
\hline \multicolumn{5}{|c|}{ Had influenza-like illness within one month of enrollment } \\
\hline No & 380 & $138(79.3)$ & $175(85.0)$ & 67 (85.9) \\
\hline Yes & 58 & 28 (16.1) & $23(11.2)$ & $7(9.0)$ \\
\hline Unknown & 20 & $8(4.6)$ & $8(3.9)$ & $4(5.1)$ \\
\hline \multicolumn{5}{|l|}{ Body mass index } \\
\hline Underweight/normal & 277 & 108 (62.1) & $120(58.3)$ & $49(62.8)$ \\
\hline Overweight/obese & 181 & $66(37.9)$ & $86(41.7)$ & $29(37.2)$ \\
\hline Pregnant & 25 & $12(6.9)$ & $11(5.3)$ & $2(2.6)$ \\
\hline Chronic heart disease & 15 & $7(4.0)$ & $5(2.4)$ & $3(3.8)$ \\
\hline Diabetes & 49 & $23(13.2)$ & $15(7.3)$ & $11(14.1)$ \\
\hline Lung disease & 100 & $47(27.0)$ & $33(16.0)$ & $20(25.6)$ \\
\hline Immunocompromised $\S$ & 65 & $35(20.1)$ & $13(6.3)$ & $17(21.8)$ \\
\hline HIV & 57 & $32(18.4)$ & $12(5.8)$ & $13(16.7)$ \\
\hline Smoker & 317 & $121(69.5)$ & $147(71.4)$ & $49(62.8)$ \\
\hline
\end{tabular}

${ }^{*}$ Enrolled before November 13, 2009; ${ }^{\dagger}$ Enrolled on or after November 13 , 2009; did not receive pH1N1 vaccine; ${ }^{\ddagger}$ Enrolled on or after November 13, 2009; received $\mathrm{pH} 1 \mathrm{~N} 1$ vaccine; ${ }^{\S}$ Participants were coded as immunocompromised if they had any of the following conditions: cancer, HIV, chemotherapy or steroid treatment

Through the use of questionnaire data and serological testing, we measured the prevalence of $\mathrm{pH} 1 \mathrm{~N} 1$ and investigated associations between seropositivity for $\mathrm{pH} 1 \mathrm{~N} 1$ and socioeconomic, clinical and other putative determinants of $\mathrm{pH} 1 \mathrm{~N} 1$ infection among adults presenting at three clinics in inner city Winnipeg (Manitoba). The results of the present study provide guidance for the planning of appropriate public health and health care responses to future influenza outbreaks.
Study population and setting

\section{METHODS}

Adults presenting to three inner city community clinics in Winnipeg from October 2009 to December 2009 were recruited as study participants $(n=458)$ using convenience sampling. For the first three weeks of participant enrollment, only adults who had not received the pH1N1 vaccine were eligible to participate in the study. Starting on November 13, 2009, this eligibility criterion was removed due to the rollout of the $\mathrm{pH} 1 \mathrm{~N} 1$ mass vaccination campaign. Among participants enrolled after November 13, 2009, the positivity outcome does not distinguish between seroconversion due to $\mathrm{pH} 1 \mathrm{~N} 1$ infection or receipt of the pH1N1 vaccine. The analysis was stratified according to this criterion change.

\section{Data collection}

Potential participants were informed of the study by clinic staff and interested participants were reviewed by the research nurse. Following receipt of informed consent, a questionnaire was administered to collect demographic, risk factor and symptom information, and a venous blood sample was collected. The blood specimens were transferred to Cadham Provincial Laboratory (Winnipeg, Manitoba) for hemagglutination inhibition assay (HIA) testing. Participants received a small honorarium (\$20) for their participation.

\section{Laboratory methods}

The HIA was performed according to standard protocol (8) using the original A/California/04/2009 H1N1 virus strain isolate provided by the Canadian National Microbiology Laboratory (Winnipeg, Manitoba). Virus stocks were prepared at Cadham Provincial Laboratory according to standard procedure (8). Briefly, a 1:10 serial dilution of the virus stock was prepared in phosphate buffered saline (PBS). Ten-day-old embryonated chicken eggs were inoculated with $100 \mu \mathrm{L}$ of one of the three virus dilutions (neat, $1: 10$ and 1:100). The eggs were incubated at $37^{\circ} \mathrm{C}$ for three days and then chilled at $4^{\circ} \mathrm{C}$ overnight. The allantoic fluid was collected using sterile $10 \mathrm{~mL}$ pipettes and $1 \mathrm{~mL}$ virus aliquots were prepared and stored at $-70^{\circ} \mathrm{C}$. Sera were treated with receptor-destroying enzymes and hemadsorbed on guinea pig red blood cells. A 1:10 dilution of the serum specimens was prepared, followed by 1:2 serial dilutions in $25 \mu \mathrm{L}$ PBS in $96 \mu \mathrm{L}$ well plates. Subject specimens were diluted in rows B though F of the microtitre plate. Twenty-five microlitres of PBS containing four hemagglutination units of the H1N1 California strain virus were added to each well. Row A of the microtitre plate was used as a control, and $25 \mu \mathrm{L}$ of uninfected allantoic fluid was added to each well. The plate was incubated for $30 \mathrm{~min}$ at room temperature, then $50 \mu \mathrm{L}$ of $0.8 \%$ guinea pig red blood cells was added to each well and incubated for $1 \mathrm{~h}$ at room temperature. The serum titre was expressed as the reciprocal of the highest serum dilution in which hemagglutination was inhibited.

\section{Data analysis}

The seroprevalence of $\mathrm{pH} 1 \mathrm{~N} 1$ antibodies was calculated as the proportion of specimens with HIA titres $\geq 1: 40$ (9-11) using STATA 9.2 (Stata Corporation, USA). For each prevalence estimate, an exact binomial 95\% CI was calculated using Clopper-Pearson intervals (12). Due to the change in enrollment eligibility criteria, effective November 13, 2009, and to facilitate interpretation of results given this change, all analyses were performed separately for the three groups. The three groups included those enrolled before the change in eligibility criteria, those enrolled after the change who were not vaccinated against $\mathrm{pH} 1 \mathrm{~N} 1$ and those enrolled after the change who were vaccinated against $\mathrm{pH} 1 \mathrm{~N} 1$. Participants who had received the seasonal or $\mathrm{pH} 1 \mathrm{~N} 1$ vaccine zero to six days before study enrollment were categorized as unvaccinated, because on average, antibody titres are not detectable by HIA at $\geq 1: 40$ until one week after vaccination (13). In addition, seasonal and $\mathrm{pH} 1 \mathrm{~N} 1$ influenza vaccination uptake, stratified according to eligibility for seasonal vaccination were tabulated. Body mass index (BMI) was calculated using height and weight measurements made by the research nurses at the clinics. 
TABLE 2

Estimates of pandemic H1N1 (pH1N1) positivity (hemagglutination inhibition assay titre $\geq 1: 40$ ) according to sociodemographic characteristics

\begin{tabular}{|c|c|c|c|c|c|c|}
\hline & \multicolumn{2}{|c|}{ Group A* } & \multicolumn{2}{|c|}{ Group B $^{\dagger}$} & \multicolumn{2}{|c|}{ Group $C^{\ddagger}$} \\
\hline & $\mathbf{n}$ & $\%$ Positive $(95 \% \mathrm{Cl})$ & $\mathbf{n}$ & $\%$ Positive $(95 \% \mathrm{Cl})$ & $\mathbf{n}$ & \% Positive (95\% Cl) \\
\hline Total & 174 & $5.7(2.8-10.3)$ & 206 & 15.5 (10.9-21.2) & 78 & $69.2(57.8-79.2)$ \\
\hline \multicolumn{7}{|l|}{ Sex } \\
\hline Female & 88 & $8.0(3.3-15.7)$ & 87 & $17.2(10.0-26.8)$ & 36 & $72.2(54.8-85.8)$ \\
\hline Male & 86 & $3.5(0.7-9.9)$ & 119 & $14.3(8.5-21.9)$ & 42 & 66.7 (50.5-80.4) \\
\hline \multicolumn{7}{|l|}{ Age, years } \\
\hline $18-29$ & 41 & $4.9(0.6-16.5)$ & 66 & 18.2 (9.8-29.6) & 13 & $100.0(75.3-100.0)$ \\
\hline 30-39 & 52 & $5.8(1.2-15.9)$ & 30 & $6.7(0.8-22.1)$ & 15 & $53.3(26.6-78.7)$ \\
\hline $40-49$ & 56 & $8.9(3.0-19.6)$ & 60 & $13.3(5.9-24.6)$ & 31 & $64.5(45.4-80.8)$ \\
\hline$\geq 50$ & 25 & $0.0(0.0-13.7)$ & 50 & $20.0(10.0-33.7)$ & 19 & $68.4(43.4-87.4)$ \\
\hline \multicolumn{7}{|l|}{ Ethnicity } \\
\hline Aboriginal & 99 & $7.1(2.9-14.0)$ & 142 & $16.9(11.1-24.1)$ & 55 & 74.5 (61.0-85.3) \\
\hline Caucasian & 58 & $3.4(0.4-11.9)$ & 50 & $10.0(3.3-21.8)$ & 19 & $52.6(28.9-75.6)$ \\
\hline Other & 17 & $5.9(0.1-28.7)$ & 14 & $21.4(4.7-50.8)$ & 4 & $75.0(19.4-99.4)$ \\
\hline \multicolumn{7}{|l|}{ Education } \\
\hline High school graduate & 81 & $7.4(2.8-15.4)$ & 81 & $11.1(5.2-20.0)$ & 29 & $58.6(38.9-76.5)$ \\
\hline Not a high school graduate & 84 & $4.8(1.3-11.7)$ & 113 & $18.6(11.9-27.0)$ & 39 & $71.8(55.1-85.0)$ \\
\hline Unknown & 9 & $0.0(0.0-33.6)$ & 12 & $16.7(2.1-48.4)$ & 10 & $90.0(55.5-99.7)$ \\
\hline \multicolumn{7}{|l|}{ Employed } \\
\hline No & 122 & $5.7(2.3-11.5)$ & 155 & $14.8(9.6-21.4)$ & 65 & $64.6(51.8-76.1)$ \\
\hline Yes & 50 & $4.0(0.5-13.7)$ & 48 & $14.6(6.1-27.8)$ & 13 & $92.3(64.0-99.8)$ \\
\hline Unknown & 2 & - & 3 & - & 0 & - \\
\hline \multicolumn{7}{|l|}{ Annual household income } \\
\hline$<\$ 10,000$ & 81 & $6.2(2.0-13.8)$ & 113 & $18.6(11.9-27.0)$ & 48 & $66.7(51.6-79.6)$ \\
\hline$\$ 10,000-29,999$ & 44 & $6.8(1.4-18.7)$ & 62 & $14.5(6.9-25.8)$ & 20 & $75.0(50.9-91.3)$ \\
\hline$\geq \$ 30,000$ & 32 & $3.1(0.1-16.2)$ & 15 & $0.0(0.0-21.8)$ & 4 & $75.0(19.4-99.4)$ \\
\hline Declined to answer & 17 & $5.9(0.1-28.7)$ & 16 & $12.5(1.6-38.3)$ & 6 & $66.7(22.3-95.7)$ \\
\hline \multicolumn{7}{|l|}{ Location of residence } \\
\hline Inner city & 106 & $4.7(1.5-10.7)$ & 133 & $18.8(12.5-26.5)$ & 51 & $72.5(58.3-84.1)$ \\
\hline Suburb/rural & 40 & $10.0(2.8-23.7)$ & 42 & $7.1(1.5-19.5)$ & 9 & $77.8(40.0-97.2)$ \\
\hline Unknown & 28 & $3.6(0.1-18.3)$ & 31 & $12.9(3.6-29.8)$ & 18 & $55.6(30.8-78.5)$ \\
\hline
\end{tabular}

${ }^{*}$ Enrolled before November 13, 2009; ${ }^{\dagger}$ Enrolled on or after November 13, 2009; did not receive pH1N1 vaccine; ${ }^{\ddagger}$ Enrolled on or after November 13, 2009; received pH1N1 vaccine

Institutional review board approval was obtained from the Health Research Ethics Board of the University of Manitoba (Winnipeg, Manitoba) and the Health Information Privacy Committee of Manitoba Health and Healthy Living. Site access approval was obtained from the Winnipeg Regional Health Authority.

\section{RESULTS}

The average age of study participants was 39 years. Forty-six per cent were female, 65\% identified their ethnicity as Aboriginal (189 First Nations, 104 Métis and three Inuit), and the average BMI was $28 \mathrm{~kg} / \mathrm{m}^{2}$. Forty-two per cent indicated that they had graduated from high school, $53 \%$ reported an annual household income of $<\$ 10,000$ and $63 \%$ reported living in the inner city. Eleven per cent reported having diabetes and $12 \%$ reported being infected with HIV. Thirteen per cent indicated that they had had ILI in the previous month, and $23 \%$ of the overall sample reported having received the seasonal influenza vaccine during the current influenza season.

Table 1 summarizes the distribution of sociodemographic and risk factor characteristics for the three study subsamples. Those enrolled before November 13, 2009, were slightly younger, with a median age of 38 years compared with 41 and 43.5 years of age among those enrolled after the criteria change who were not vaccinated and vaccinated, respectively. Fewer among the early enrollment group self-identified as Aboriginal, while more had completed high school and were employed. Those who were enrolled after the criteria change and were not vaccinated against $\mathrm{pH} 1 \mathrm{~N} 1$ were less likely to have diabetes, chronic heart disease or be immunocompromised.
Rates of pH1N1 seropositivity

Among participants enrolled before the eligibility criteria change pertaining to vaccination on November 13, 2009, 5.7\% tested positive for antibodies against pH1N1 by HIA (Table 2). Among participants enrolled posteligibility criteria change, but not vaccinated against pH1N1, 15.5\% tested positive for pH1N1 antibodies. Women were more likely to test positive both before and after the eligibility criteria change (8.0\% and $17.2 \%$, respectively) than men $(3.5 \%$ and $14.3 \%$, respectively). According to age group, positivity among those who had not received the $\mathrm{pH} 1 \mathrm{~N} 1$ vaccine ranged from $4.9 \%$ (age 18 to 29 years, precriteria change) to $20 \%$ (age $\geq 50$ years, postcriteria change). Seventynine per cent of participants in the age $\geq 50$ years category were between the ages of 50 and 59 years. Participants of Aboriginal and 'other' ethnicities were more likely to test positive than Caucasian participants in all three study subsamples (Table 2). For example, among those enrolled before the eligibility criteria change, 3.4\% of Caucasians were positive, compared with 7.1\% of Aboriginals and 5.9\% of 'other' ethnicities.

Among participants enrolled before the eligibility criteria change, unemployed individuals were more likely to test positive than employed participants. Participants in the highest annual household income category were less likely to test positive compared with participants in lower income categories. Participants residing in suburbs and rural areas were more likely to test positive than those residing in the inner city, and this pattern reversed after the criteria change. Also, positivity was higher among participants who were overweight or obese $(7.4 \%)$ compared with those with normal or low BMI (3.0\%). 
TABLE 3

Estimates of pandemic H1N1 (pH1N1) positivity (hemagglutination inhibition assay titre $\geq 1: 40$ ) according to risk factors for infection and/or severe disease

\begin{tabular}{|c|c|c|c|c|c|c|}
\hline & \multicolumn{2}{|c|}{ Group A* } & \multicolumn{2}{|c|}{ Group B ${ }^{\dagger}$} & \multicolumn{2}{|c|}{ Group C $C^{\ddagger}$} \\
\hline & $\mathbf{n}$ & \% Positive $(95 \% \mathrm{Cl})$ & $\mathbf{n}$ & $\%$ Positive $(95 \% \mathrm{Cl})$ & $\mathbf{n}$ & $\%$ Positive $(95 \% \mathrm{Cl})$ \\
\hline Total & 174 & $5.7(2.8-10.3)$ & 206 & $15.5(10.9-21.2)$ & 78 & $69.2(57.8-79.2)$ \\
\hline \multicolumn{7}{|c|}{ Contact with children $0-5$ years of age } \\
\hline No & 147 & $4.8(1.9-9.6)$ & 176 & 14.8 (9.9-20.9) & 67 & $65.7(53.1-76.8)$ \\
\hline Yes & 25 & $8.0(1.0-26.0)$ & 29 & 20.7 (8.0-39.7) & 11 & 90.9 (58.7-99.8) \\
\hline Unknown & 2 & - & 1 & - & 0 & - \\
\hline \multicolumn{7}{|c|}{ Had influenza-like illness within one month of enrollment } \\
\hline No & 138 & $5.8(2.5-11.1)$ & 175 & $16.0(10.9-22.3)$ & 67 & $68.7(56.2-79.4)$ \\
\hline Yes & 28 & $7.1(0.9-23.5)$ & 23 & $17.4(5.0-38.8)$ & 7 & $71.4(29.0-96.3)$ \\
\hline Unknown & 8 & $0.0(0.0-36.9)$ & 8 & $0.0(0.0-36.9)$ & 4 & $75.0(19.4-99.4)$ \\
\hline \multicolumn{7}{|l|}{ Body mass index } \\
\hline Underweight/normal & 66 & $3.0(0.4-10.5)$ & 87 & $17.2(10.0-26.8)$ & 28 & $67.9(47.6-84.1)$ \\
\hline Overweight/obese & 108 & $7.4(3.3-14.1)$ & 125 & $15.2(9.4-22.7)$ & 44 & $75.0(59.7-86.8)$ \\
\hline \multicolumn{7}{|l|}{ Pregnant } \\
\hline No & 162 & $5.6(2.6-10.3)$ & 195 & $15.9(11.1-21.8)$ & 76 & $68.4(56.7-78.6)$ \\
\hline Yes & 12 & $8.3(0.2-38.5)$ & 11 & $9.1(0.2-41.3)$ & 2 & $100.0(15.8-100.0)$ \\
\hline \multicolumn{7}{|l|}{ Chronic heart disease } \\
\hline No & 167 & $5.4(2.5-10.0)$ & 201 & $15.9(11.2-21.7)$ & 75 & $69.3(57.6-79.5)$ \\
\hline Yes & 7 & $14.3(0.4-57.9)$ & 5 & $0.0(0.0-52.2)$ & 3 & 66.7 ( 9.4-99.2) \\
\hline \multicolumn{7}{|l|}{ Diabetes } \\
\hline No & 151 & $5.3(2.3-10.2)$ & 191 & $15.7(10.9-21.7)$ & 67 & $67.2(54.6-78.2)$ \\
\hline Yes & 23 & $8.7(1.1-28.0)$ & 15 & $13.3(1.7-40.5)$ & 11 & 81.8 (48.2-97.7) \\
\hline \multicolumn{7}{|l|}{ Lung disease } \\
\hline No & 127 & $3.9(1.3-8.9)$ & 173 & $15.6(10.5-21.9)$ & 58 & 70.7 (57.3-81.9) \\
\hline Yes & 47 & $10.6(3.5-23.1)$ & 33 & $15.2(5.1-31.9)$ & 20 & $65.0(40.8-84.6)$ \\
\hline \multicolumn{7}{|l|}{ Immunocompromised ${ }^{\S}$} \\
\hline No & 139 & $6.5(3.0-11.9)$ & 193 & $15.5(10.7-21.4)$ & 61 & $72.1(59.2-82.9)$ \\
\hline Yes & 35 & $2.9(0.1-14.9)$ & 13 & $15.4(1.9-45.4)$ & 17 & 58.8 (32.9-81.6) \\
\hline \multicolumn{7}{|l|}{ HIV } \\
\hline No & 142 & $6.3(2.9-11.7)$ & 194 & $15.5(10.7-21.3)$ & 65 & $69.2(56.6-80.1)$ \\
\hline Yes & 32 & $3.1(0.1-16.2)$ & 12 & $16.7(2.1-48.4)$ & 13 & $69.2(38.6-90.9)$ \\
\hline \multicolumn{7}{|l|}{ Smoker } \\
\hline No & 53 & $5.7(1.2-15.7)$ & 59 & $15.3(7.2-27.0)$ & 29 & $69.0(49.2-84.7)$ \\
\hline Yes & 121 & $5.8(2.4-11.6)$ & 147 & $15.6(10.2-22.5)$ & 49 & $69.4(54.6-81.7)$ \\
\hline \multicolumn{7}{|c|}{ Eligible for seasonal influenza vaccine ${ }^{\pi}$} \\
\hline No & 79 & $3.8(0.8-10.7)$ & 140 & $15.7(10.1-22.8)$ & 44 & $72.7(57.2-85.0)$ \\
\hline Yes & 95 & $7.4(3.0-14.6)$ & 66 & $15.2(7.5-26.1)$ & 34 & $64.7(46.5-80.3)$ \\
\hline \multicolumn{7}{|c|}{ Received seasonal influenza vaccine } \\
\hline No & 172 & $5.8(2.8-10.4)$ & 169 & $14.8(9 .-21.1)$ & 24 & $70.8(48.9-87.4)$ \\
\hline Yes & 2 & $0.0(0.0-84.2)$ & 37 & $18.9(8.0-35.2)$ & 54 & $68.5(54.4-80.5)$ \\
\hline \multicolumn{7}{|c|}{ Received pH1N1 vaccine ${ }^{\star *}$} \\
\hline No & 174 & $5.7(2.8-10.3)$ & 206 & $15.5(10.9-21.2)$ & 6 & $33.3(4.3-77.7)$ \\
\hline Yes & 0 & - & 0 & - & 72 & $72.2(60.4-82.1)$ \\
\hline
\end{tabular}

${ }^{\star}$ Enrolled before November 13, 2009; ${ }^{\dagger}$ Enrolled on or after November 13, 2009; did not receive pH1N1 vaccine; ${ }^{\ddagger}$ Enrolled on or after November 13, $2009 ;$ received pH1N1 vaccine; ' Participants were coded as immunocompromised if they had any of the following conditions: cancer, HIV, chemotherapy or steroid treatment; "Eligibility for seasonal influenza vaccination was established based on the criteria used by Manitoba Health. Those who were 65 years of age or older, pregnant, receiving steroid or chemotherapy, or with one of the following conditions were considered to be eligible to receive the seasonal influenza vaccine: cancer, chronic heart disease, lung disease, diabetes, tuberculosis or HIV; ${ }^{* *}$ Seventy-eight study participants received the pH1N1 vaccine. Of these 78 , six provided a serum sample for the study less than one week after having received the $\mathrm{pH} 1 \mathrm{~N} 1$ vaccine and, therefore, for hemagglutination inhibition assay result interpretation were categorized as not having received this vaccine

Positivity was high among those who had received the pH1N1 vaccine, compared with those who had not (72.2\% compared with $5.7 \%$ to $33.3 \%$, depending on subsample considered) (Table 3). Participants in contact with children up to five years of age were more likely to test positive for antibodies against pH1N1. Participants who had experienced ILI symptoms within the month before study enrollment were also more likely to test positive. Before the study eligibility criteria change, participants who would have been eligible to receive the seasonal influenza vaccine in Manitoba due to chronic disease or being 65 years of age or older were more likely to test positive. After the criteria change, 


\section{TABLE 4}

Patterns of seasonal and pandemic H1N1 (pH1N1) vaccination uptake stratified according to seasonal vaccine eligibility criteria

\begin{tabular}{|c|c|c|c|c|c|c|c|c|c|c|}
\hline & \multirow[b]{2}{*}{ n (\%) } & \multicolumn{3}{|c|}{ Group A* } & \multicolumn{3}{|c|}{ 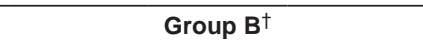 } & \multicolumn{3}{|c|}{ Group $C^{\ddagger}$} \\
\hline & & n (\%) & No, n (\%) & Yes, n (\%) & n (\%) & No, n (\%) & Yes, n (\%) & n (\%) & No, n (\%) & Yes, n (\%) \\
\hline $\begin{array}{l}\text { Subsample not eligible for } \\
\text { seasonal vaccine }\end{array}$ & $195(42.6)$ & $79(45.4)$ & 78 (98.7) & $1(1.3)$ & $184(64.8)$ & $132(71.7)$ & $52(28.26)$ & $184(64.8)$ & $140(76.1)$ & $44(23.9)$ \\
\hline $\begin{array}{l}\text { Subsample eligible for } \\
\text { seasonal vaccine }\end{array}$ & $263(57.4)$ & $95(54.6)$ & 89 (93.7) & $6(6.3)$ & $100(35.2)$ & $52(52.0)$ & $48(48.0)$ & $100(35.2)$ & $66(66.0)$ & $34(34.0)$ \\
\hline
\end{tabular}

${ }^{*}$ Enrolled before November 13, 2009; ${ }^{\dagger}$ Enrolled on or after November 13, 2009; did not receive pH1N1 vaccine; ${ }^{\ddagger}$ Enrolled on or after November 13, 2009; received pH1N1 vaccine

this effect largely disappeared; however, among those who received the pH1N1 vaccine, seroposivity was higher among those with diabetes.

Rates of vaccination

In the total sample, $28 \%$ received the $\mathrm{pH} 1 \mathrm{~N} 1$ vaccine (Table 4$)$. A higher percentage of those who were eligible to receive the seasonal flu vaccine were vaccinated against seasonal flu at both time points $(6 \%$ and $48 \%$, respectively) and pH1N1 (34\%) compared with those who did not meet the eligibility criteria (1\%, $28 \%$ and $24 \%$, respectively).

\section{DISCUSSION}

Our findings suggest that the marginalized, inner city population of Winnipeg may be at high risk for influenza infection and have lower than recommended rates of vaccination. Among those who did not receive the $\mathrm{pH} 1 \mathrm{~N} 1$ vaccine, the positivity rate in the pre-November 13,2009 , subsample was $5.7 \%$, which was higher than post-first-wave positivity among pregnant women presenting for prenatal screening in Winnipeg, estimated to be $4 \%$ according to a serological survey (14). After the November 13, 2009, enrollment criteria change, the positivity rate in the nonimmunized subsample was $16 \%$. This increase likely represented the progression of the outbreak during the second wave, along with seroconversion resulting from unreported vaccination. The much higher positivity among the vaccinated subsample may be due to seroconversion following $\mathrm{pH} 1 \mathrm{~N} 1$ vaccination.

Positivity was relatively high among female and Aboriginal participants, and those with less education and lower income. It has been suggested that the higher rates of confirmed pH1N1 infection among women identified through surveillance data is due to higher testing rates among women. However, the present study tested approximately equal numbers of men and women, yet a higher positivity was found among women. This suggests that there is an increased risk for acquiring influenza infection among females, potentially due to greater contact with children compared with males, through parenting or grandparenting $(15,16)$. Consistent with other findings $(15,16)$, contact with children is related to positivity. Another possible explanation may be related to hormonal factors affecting immune response.

The higher positivity among participants of Aboriginal and 'other' ethnicities is consistent with surveillance data from Manitoba and other provinces (17), and is likely explained by greater exposure to circulating influenza (18). Higher rates of positivity were also found among the subsample in the lowest income categories and among those who had not graduated from high school. Participants residing in suburbs and rural areas were more likely to test positive early in the study compared with inner city residents, and this pattern changed among the subsample enrolled after November 13, 2009. This is similar to the pattern observed by geography for the province of Manitoba, whereby the northern residents experienced a high incidence of infection in the first wave of the outbreak and then a much smaller incidence in the second wave of the outbreak, believed to be due to herd immunity $(14,19)$.

Studies have reported lower rates of infection among older age groups (20). This trend was not seen in this population, possibly due to the high rates of immunocompromise, which may have also explained greater vulnerability to infection. Alternatively, it has been reported that cross-reactive antibodies are more common among individuals born before 1950 (21).
Despite the fact that the $\mathrm{pH} 1 \mathrm{~N} 1$ vaccine was made available to all Manitobans in the fall of 2009, with priority given to individuals considered to be at higher risk for severe disease and complications, including proxies of socioeconomic status and marginalization $(22,23)$, rates of vaccine uptake among study participants were low - comparable with the 2005 vaccination rate among Manitobans without chronic diseases (17\%) (24). Of particular concern is the fact that only onethird of those who belonged to priority groups for vaccination received the $\mathrm{pH} 1 \mathrm{~N} 1$ vaccine. Also, participants in the present study may have been more likely to receive vaccination compared with other lowincome, inner city adults because they were recruited in clinics. It has been found that individuals who are not already connected to health services are less likely to be vaccinated (7). In both the context of typical influenza seasons and influenza outbreaks in Manitoba, vaccination uptake among individuals at the highest risk for severe disease and complications falls considerably short of the national target of $80 \%$ (24) and this gap should be addressed through greater efforts to provide acceptable, low-threshold opportunities for education and administration of vaccines to inner city populations during the typical influenza seasons as well as in the context of epidemics.

\section{Limitations}

Convenience sampling was used for the present study due to the lack of a sampling frame for low-income, inner city populations. Partway through the study, the enrollment criteria were changed to allow individuals who had received the $\mathrm{pH} 1 \mathrm{~N} 1$ vaccine to participate in the study. Among participants enrolled after the criteria change on November 13, 2009, who received the $\mathrm{pH} 1 \mathrm{~N} 1$ vaccine, the positivity outcome does not distinguish between seroconversion due to $\mathrm{pH} 1 \mathrm{~N} 1$ infection or receipt of the $\mathrm{pH} 1 \mathrm{~N} 1$ vaccine, which is the reason why the analysis was stratified according to this criterion change. Furthermore, differences in baseline characteristics between the subsamples enrolled pre- and posteligibility criteria change, particularly those associated with positivity, such as sex and ethnicity, supported the stratification of the sample. This stratification resulted in small sample sizes within each group, which reduced the power of the study and, therefore, formal statistical significance testing was not performed. However, exact CIs were presented for each prevalence estimate to permit assessment of the reliability of these estimates.

It is possible that some positive test results may be misclassifications due to cross-reactivity with non-neutralizing antibodies produced in response to receipt of the seasonal influenza vaccine or infection with heterologous strains, and may not represent $\mathrm{pH} 1 \mathrm{~N} 1$ infection (25). It is also possible that some individuals may not have reported having received the $\mathrm{pH} 1 \mathrm{~N} 1$ vaccine because they forgot or did not know what vaccine they had been given. Given that recruitment took place during the vaccination campaign, and a short period of time would have passed between vaccination and study enrollment, the effect of the resulting bias is likely minimal. Guinea pig erythrocytes were used for HIA in the present study, but some other seroprevalence studies have used turkey red blood cells; therefore, because the cell type used may influence agglutination patterns, consideration should be given to the cell type used for HIA when comparing results of different studies. 


\section{CONCLUSION}

Positivity for pH1N1 was high among low-income adults accessing clinics in Winnipeg's inner city compared with the general population. Vaccination rates for both seasonal and $\mathrm{pH} 1 \mathrm{~N} 1$ influenza were low considering that a high proportion of the sample would have been specifically targeted for vaccination due to the presence of chronic conditions. Given this, and that vaccination is the most effective means to protect vulnerable populations from disease (26), more effective methods are required to develop and rapidly implement vaccination strategies specifically designed to reach a high proportion of these vulnerable populations, particularly Aboriginal persons and those at highest risk for severe disease and complications. When planning for future influenza outbreaks, it is important to incorporate strategies for the prevention, control, and care of influenza among lowincome and inner city adults.

FINANCIAL SUPPORT: This study was supported by the International Centre for Infectious Diseases through a grant from the Public Health Agency of Canada.

DISCLAIMERS: The Public Health Agency of Canada played no role in the design or conduct of the study. The Government of Manitoba, the Manitoba Ministry of Health, International Centre for Infectious Diseases, and the Public Health Agency of Canada bear no responsibility for the analysis of the data or the interpretation of the results.

\section{REFERENCES}

1. Cutler J, Schleihauf E, Hatchette T, et al. Investigation of the first cases of human-to-human infection with the new swine-origin influenza A (H1N1) virus in Canada. CMAJ 2009;181:159-63.

2. CDC Branch, Manitoba Health. Influenza in Manitoba - 2008/2009 Season. July 1, 2009. <www.gov.mb.ca/health/publichealth/ surveillance/influenza/0809season.pdf $>$ (Accessed July 19, 2010).

3. CDC Branch, Manitoba Health. Influenza in Manitoba - 2009/2010 Season. April 10, 2010. <www.gov.mb.ca/health/publichealth/ surveillance/influenza/0910season.pdf> (Accessed July 19, 2010).

4. Embree J. Pandemic 2009 (A) H1N1 influenza (swine flu)-the Manitoba experience. Biochem Cell Biol 2010:88:589-93.

5. Public Health Agency of Canada. Flu Watch for September 6, 2009 to September 12, 2009 (Week 36). <www.phac-aspc.gc.cal fluwatch/09-10/w36_09/index-eng.php> (Accessed July 19, 2010).

6. Vlahov D, Coady M, Ompad D, Galea S. Strategies for improving influenza immunization rates among hard-to-reach populations. J Urban Health 2007;84:616-31.

7. Bryant WK, Ompad DC, Sisco S, et al. Determinants of influenza vaccination in hard-to-reach urban populations. Prev Med 2006;43:60-70.

8. Webster R, Cox N, Stohr K. WHO manual on animal influenza diagnosis and surveillance. World Health Organization, 2002.
9. Sandbulte M, Jimenez G, Boon A, Smith L, Treanor J, Webby R. Cross-reactive neuraminidase antibodies afford partial protection against $\mathrm{H} 5 \mathrm{~N} 1$ in mice and are present in unexposed humans. PLoS Med 2007;4:e59.

10. de Jong JC, Palache AM, Beyer WE, Rimmelzwaan GF, Boon AC, Osterhaus AD. Haemagglutination-inhibiting antibody to influenza virus. Dev Biol (Basel) 2003;115:63-73.

11. Potter C, Oxford J. Determinants of immunity to influenza infection in man. Br Med Bull 1979;35:69-75.

12. Clopper C, Pearson ES. The use of confidence or fiducial limits illustrated in the case of the binomial. Biometrika 1934;26:404-13.

13. Kunzel W, Glathe H, Engelmann H, Van Hoecke C. Kinetics of humoral antibody response to trivalent inactivated split influenza vaccine in subjects previously vaccinated or vaccinated for the first time. Vaccine 1996;14:1108-10.

14. Mahmud SM, Becker M, Keynan Y, et al. Estimated cumulative incidence of pandemic (H1N1) influenza among pregnant women during the first wave of the 2009 pandemic. CMAJ 2010;182:1522-4.

15. Fiore AE, Neuzil KM. 2009 Influenza A(H1N1) monovalent vaccines for children. JAMA 2010;303:73-4.

16. Loeb M, Russell ML, Moss L, et al. Effect of influenza vaccination of children on infection rates in Hutterite communities: A randomized trial. JAMA 2010;303:943-50.

17. Public Health Agency of Canada. FluWatch. $<$ http://origin.phacaspc.gc.ca/fluwatch/> (Accessed July 19, 2010).

18. La Ruche G, Tarantola A, Barboza P, Vaillant L, Gueguen J, Gastellu-Etchegorry M, for the epidemic intelligence team at InVS. The 2009 pandemic H1N1 influenza and indigenous populations of the Americas and the Pacific. Euro Surveill 2009;14:19366.

19. Pollock SL, Sagan M, Oakley L, Fontaine J, Poffenroth L. Investigation of a pandemic H1N1 influenza outbreak in a remote First Nations community in northern Manitoba, 2009. Can J Public Health 2012;103:90-3.

20. Hancock K, Veguilla V, Lu X, et al. Cross-reactive antibody responses to the 2009 pandemic H1N1 influenza virus. N Engl J Med 2009;361:1945-52.

21. Hardelid P, Andrews Ni, Hoschler K, et al. Assessment of baseline age-specific antibody prevalence and incidence of infection to novel influenza AH1N1 2009. Health Technol Assess 2010;14:115-92.

22. Manitoba Health and Healthy Living. Seasonal Flu. <www.gov. mb.ca/health/flu/> (Accessed July 19, 2010).

23. Manitoba Health and Healthy Living. Media Bulletin. Flu Bulletin \#2, October 21, 2009. <www.gov.mb.ca/chc/press/top/2009/10/2009. 10-21-141700-7026.html> (Accessed July 19, 2010).

24. Kwong JC, Rosella LC, Johansen H. Trends in influenza vaccination in Canada, 1996/1997 to 2005. Health Rep 2007;18:9-19.

25. Katz J, Hancock K, Veguilla V, et al. Serum cross-reactive Antibody response to a novel influenza $A(H 1 N 1)$ virus after vaccination with seasonal influenza vaccine. MMWR 2009;58:521-4.

26. Tosh PK, Jacobson RM, Poland GA. Influenza vaccines: From surveillance through production to protection. Mayo Clinic Proc 2010;85:257-73. 


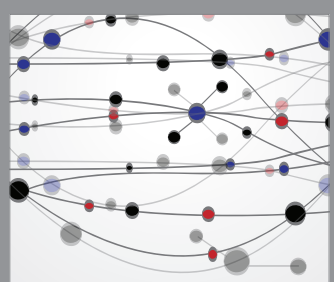

The Scientific World Journal
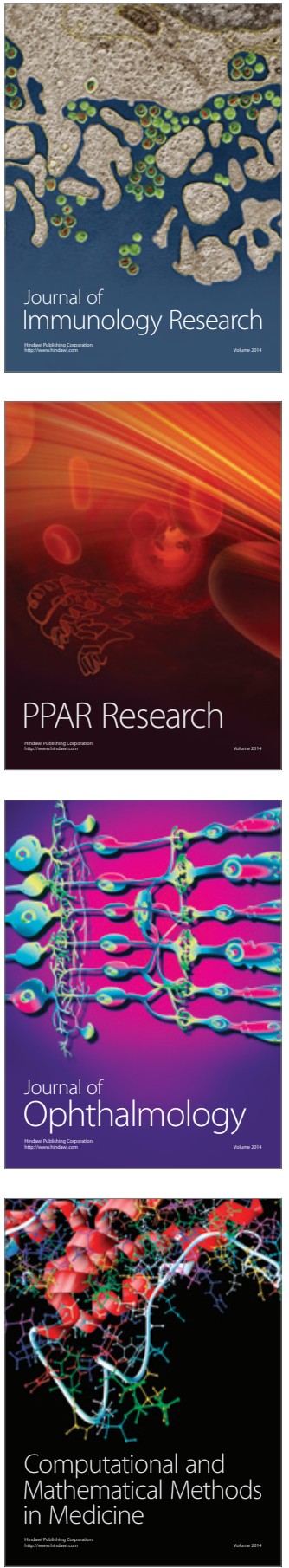

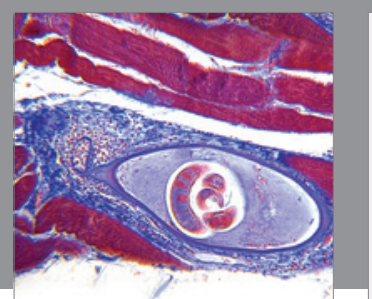

Gastroenterology Research and Practice

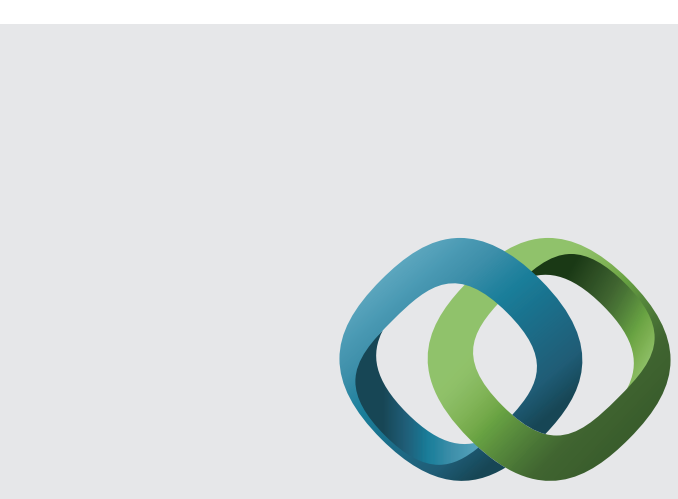

\section{Hindawi}

Submit your manuscripts at

http://www.hindawi.com
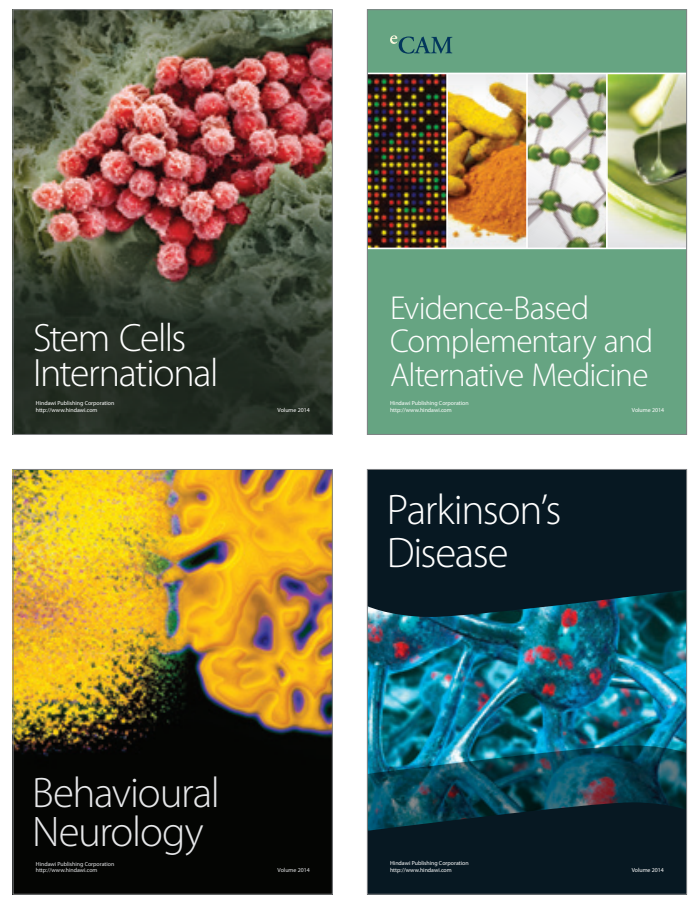
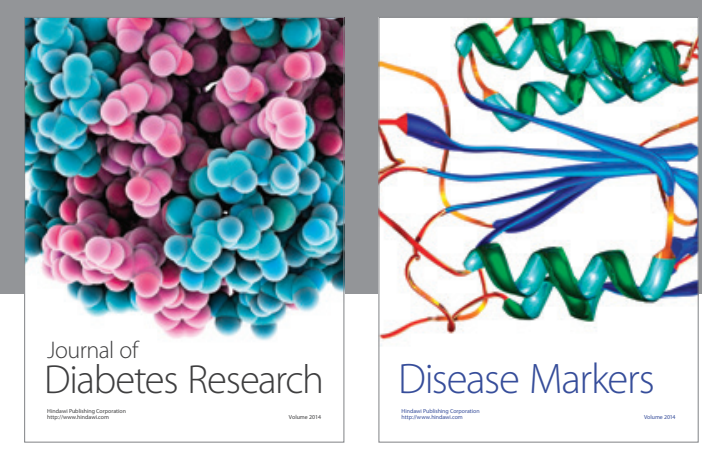

Disease Markers
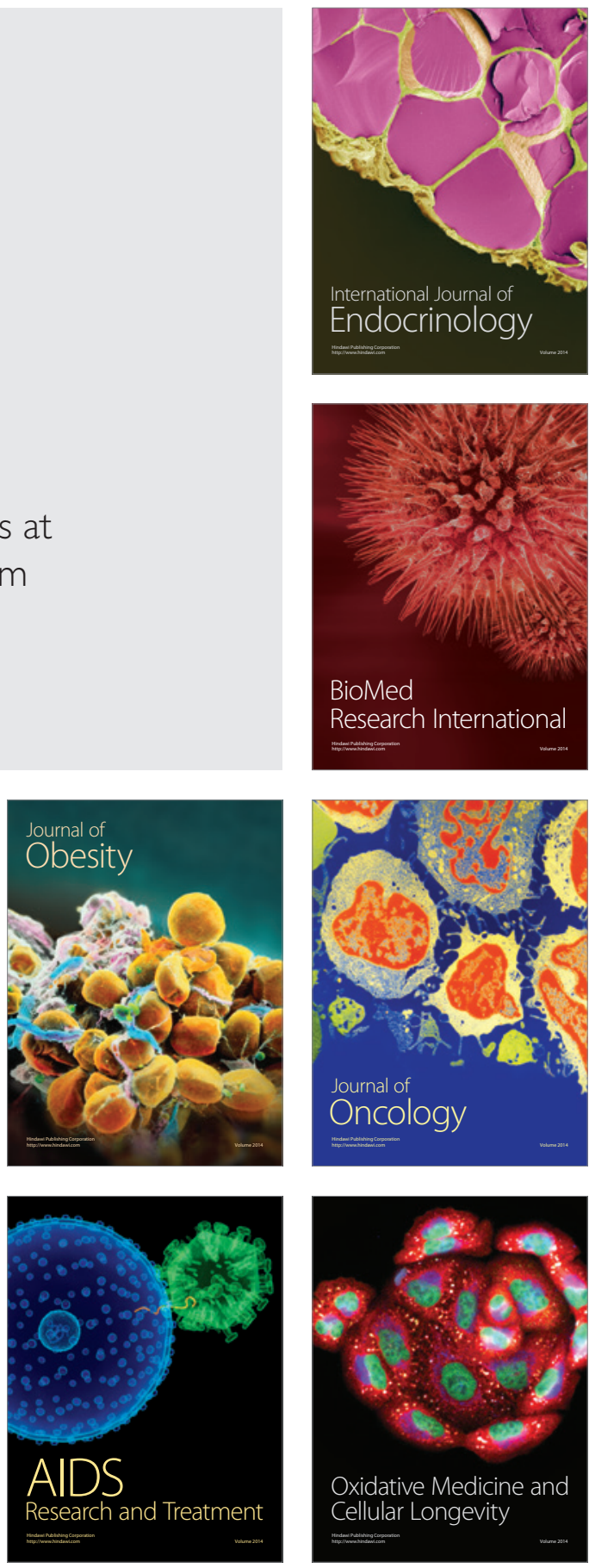